\title{
THE NEW HISTORY OF \\ PSYCHOANALYSIS: TOWARDS A RICHER AND MORE NUANCED NARRATIVE
}

\author{
MICHAL SHAPIRA
}

History Department, Tel Aviv University

E-mail: michalıs@post.tau.ac.il

By 1939, W. H. Auden was able to publish a poem in memory of Sigmund Freud saying, "if often he was wrong and, at times, absurd, to us he is no more a person now but a whole climate of opinion." "Indeed, despite the opposition to Freud's new discipline from the medical establishment and some members of the public, psychoanalysis in its various proliferations had become popular in Europe as early as before World War II, and its terminology had become part of everyday language. More importantly, it propounded new possibilities for diagnosing personal problems and understanding sociopolitical issues. When Freud was asked in 1923 whether he would like to "psycho-analyze Europe in the hope of finding a cure for her ills," he replied, "I never take a patient to whom I can offer no hope." ${ }^{\prime 2}$ But as the twentieth century progressed, Freud and his followers developed ideas that engaged directly and indirectly with the personal and political questions of the age of catastrophes.

Nonetheless, from around the 1970s, psychoanalysis was increasingly marginalized, especially in the USA; and since the 1980s Herzog's book, the mainstream media, psychologists and prominent feminists argued fiercely against the relevance of Freud in the fields of psychiatry and psychology. Some claimed that psychoanalytic ideas might, at best, be found in departments of comparative literature, cinema or cultural studies. Others emphasized the misogynist overtones in Freud's writing. In the 1990s, the feminist activist Gloria Steinem claimed (in a radical statement she later modified) that "sending a woman to

W. H. Auden, "In Memoriam Sigmund Freud," in Auden, Another Time: Poems (London, 1940), 118.

2 Quoted in Nathan G. Hale, The Rise and Crisis of Psychoanalysis in the United States: Freud and the Americans, 1917-1985 (New York, 1995), 78. 
a Freudian therapist ... is not so far distant from sending a Jew to a Nazi" (quoted at 218). Even humanities scholars seeking to include psychoanalytical ideas in their research warned against its normalizing and pathologizing elements. Overall, many were puzzled at psychoanalysis's apparent overemphasis of psychic interiority rather than its relationship with prevailing political conditions.

In a provocative, original and deeply researched book, the prominent historian Dagmar Herzog argues that this common view of psychoanalysis-centered on the Oedipus complex, penis envy, infantile sexuality, psychological insularity, misogyny and homophobia - was, in fact, only one form of psychoanalysis that developed in the postwar era. She demonstrates that various other forms and uses of psychoanalysis developed during the Cold War, many of which were politically radical and morally engaged in ways that have since been forgotten. With conceptual sophistication, she meticulously reveals that there was "an extraordinary plasticity to the thought-system that evolved under the aegis of the name of Freud" (220).

The last few years have seen a surge of new books on the history of psychoanalysis. ${ }^{3}$ All of them indicate that the knowledge and practice it embodies operate in relation to prevailing sociocultural conditions, and that, in this sense, each country has "its own psychoanalysis." ${ }^{4}$ Herzog shares this assumption and adds a key contribution to the research of the new history of psychoanalysis. Aiming to recover the theories of experts such as Robert Stoller or Kurt R. Eissler, Alexander Mitscherlich and Paul Parin, all of whose work was forgotten or misunderstood, Herzog restores them to the canon of psychoanalytic, intellectual, and sociocultural postwar history. Rereading their work, and that of many activists and professionals they inspired, should change the way we write the history of psychoanalysis and of the political left. Herzog argues that psychoanalytic history did not culminate in the 1940s with a turn inward towards the unconscious, inner dynamics and psychic reality. She shows persuasively that rather than there being one version of Freud in the Cold War era, there were

Camille Robcis, The Law of Kinship: Anthropology, Psychoanalysis, and the Family in France (Ithaca, 2013); Erik Linstrum, Ruling Minds: Psychology in the British Empire (Cambridge, MA, 2016); Michal Shapira, The War Inside: Psychoanalysis, Total War and the Making of the Democratic Self in Postwar Britain (Cambridge, 2013); Joy Damousi and Mariano Ben Plotkin, eds., Psychoanalysis and Politics: Histories of Psychoanalysis under Conditions of Restricted Political Freedom (Oxford, 2012). See also Katja Guenther, Localization and Its Discontents: A Genealogy of Psychoanalysis and the Neuro Disciplines (Chicago, 2015).

4 As suggested by Edith Kurzweil, The Freudians: A Comparative Perspective (New Haven, 1989). 
in fact hundreds of different versions of his ideas. One of the main arguments that emerges from the book is that the implications of postwar psychoanalysis could be normative and conservative, as well as socially critical and even radical.

The book's six chapters cover a wide range of topics spanning the turn towards sexual conservatism and the struggles against it, Nazism's legacies in psychiatric debates, and the uses of Freudian thought to develop the radical ideas of the New Left. I will focus here on chapters 2 and 3, which I find most important, and highlight their major contributions. I will also suggest that researchers might further examine the continuity between the pre- and postwar periods, and how psychoanalysis oscillated between normative and radical social critiques, both then and at other times during its development.

Chapter 2 focuses on psychoanalytic homophobia, revealing just how pervasive it was in the 1950s. The chapter also follows the battles against it which led to the removal in 1973 of the category of homosexuality from the DSM. In the 1950s, analytic homophobia and thinking about sex evolved in direct opposition to the theories of Alfred Kinsey. Nonetheless, homophobic analytic ideas came under attack with the sexual revolution and the women's and gay rights movements of the 1960s. This heritage from the 1960 s led writers like Robert Stoller to reinvent psychoanalysis and develop anti-homophobic theories during the following decade. He argued, for example, that painful emotional experiences were at the root of all perversions, and that almost everyone-certainly not only the homosexual male-displayed some form of perverse behavior.

Herzog does indeed mention the prewar history of contradictory analytic ideas regarding homosexuality (62-75). However, I believe it would be of particular interest to examine further both the pre- and postwar periods together, and highlight the anti-homophobic efforts made in the 1950s, in order to show that there was no linear transition from conservative to radical ideas (via the 1960s), but rather a multifaceted, contradictory development, oscillating between the normative and the reformative. Indeed, this was perhaps a tension at the very heart of the psychoanalytic project throughout its existence.

As early as the interwar years in Britain, for example, the impact of psychoanalysis grew as it was advancing mostly progressive, rather than homophobic, views regarding homosexuality. Indeed, the rising status of psychoanalysis in official discourses of homosexuality in the 1950 owed much to the early efforts of Sigmund Freud himself, along with his followers, to discredit the competing research of Havelock Ellis and the 1930 s criminologists who adopted quasi-psychoanalytic thinking in their campaign for penal reform. Despite the fact that Freud saw homosexuality as an inhibition of "normal" progress leading to reproduction, he did not believe it to be a special category of subjectivity, or an innate inversion, as described by sexologists like Ellis. Freud 
advanced the radical idea that every person could make a homosexual object choice, and he was wary of attempts to alter and treat homosexuals. ${ }^{5}$

Analysts working in the Institute for the Scientific Study of Delinquency (ISTD) in London developed these ideas and called for penal reform and social change with regard to sexual offences before and after $1945 .{ }^{6}$ They used Freud's theories to suggest that "perversions" are derived from infantile sexuality. The ISTD memorandum to the 1957 Wolfenden Committee on Homosexual Offences and Prostitution, written by analyst Edward Glover, had the dual agenda of calling for reform while also carving out a special place for the expert. It can be read as a kind of psychoanalytic political manifesto that presented complex, and at times opposing, views on homosexuality. Its fundamental argument was that homosexuality per se should not be treated as a crime; however, at the same time, it was willing to label some cases of homosexuality (those associated with acts of violence, assault or the seduction of minors) as a mental disorder needing psychological treatment. ${ }^{7}$

Thus, in relation to homosexuality, we might create a stronger link between the pre- and postwar periods in order to achieve an overarching narrative of the history of psychoanalysis. Moreover, this may shed light on how the roots of anti-homophobia emerged before the war, culminating in efforts to publicly fight for legal and social change in the 1950s. We can make similar links across periods in the case of trauma, as shown below.

In chapter 3, Herzog makes a significant contribution to understanding the development of PTSD by scrutinizing the rarely studied yet crucial role of debates regarding the eligibility for reparations for Jewish Holocaust survivors. She charts the responses of pro- and anti-psychoanalytic psychiatrists in the USA, Europe and Israel to the emotional reactions of survivors. Interestingly, Freudian concepts were appropriated both by experts antagonistic to the survivors and by those sympathetic to their severe mental suffering. This is important research as it shows a missing link in the historiography from the shell shock of World War I to post-Vietnam PTSD. The research in this chapter is superb. Especially interesting is the discussion of records by doctors who opposed benefits for survivors. In what nowadays would sound absurd, these experts argued that the survivors of the worst atrocities were "oversensitive" or "neurotic," due to familial conflicts or inner problems, rather than as the result of the actual reality of murderous

$5 \quad$ Chris Waters, "Havelock Ellis, Sigmund Freud and the State: Discourses of Homosexual Identity in Interwar Britain," in Lucy Bland and Laura Doan, eds., Sexology in Culture: Labelling Bodies and Desires (Chicago, 1999), 165-8.

6 There were other analysts like Ernest Jones who continued to express more homophobic statements. On the ISTD see Shapira, The War Inside, chaps. 5, 6.

7 Edward Glover, The Social and Legal Aspects of Sexual Abnormality (London, 1945), 5-7. 
persecution. Such arguments, Herzog shows, were also tied to a resurgence of anti-Semitism in West Germany, which viewed Jews as greedy, self-interested or "gaining from illness."

However, if we disregard this postwar anti-Semitic context, it may again be informative to view the continuity of pre- and postwar developments, as in the case of homosexuality, and see how analytic logic — in this case, the focus on inner rather than external reality - served entirely opposing purposes. In Britain in the 1920s, for example, some analytic doctors treating shell shock asserted that their patients' inner psychological disposition rather than the experiences of the Great War were the prime cause of soldiers' trauma; this assertion did, however, make the case for psychological treatment rather than denying it. Similarly, during and after World War II, most British psychoanalysts emphasized "the war inside" and childhood separation trauma rather than the effects of the actual war in the form of aerial bombing; and this emphasis underpinned the call for the development of welfare services for mental health. This leads me to ask how future research might integrate the history of pre- and postwar discussions of war trauma, and shed further light on how similar logic may serve competing aims and outcomes. ${ }^{8}$

Overall, Herzog's book and the powerfully argued case studies she includes with great originality and thoughtfulness make a major contribution to advancing us towards a more nuanced and rich narrative of the history of psychoanalysis. It also brings to mind further ideas for synthetic and integrative research on psychoanalysis in the twentieth century. Cold War Freud combines incisive theorization of a wide range of topics with careful, deep research, and sheds light on the post-Holocaust era, the sexual revolution, the gay movement, the New Left, and the age of decolonization.

8 We should, perhaps, also note that scholars like Carl Schorske and William McGrath believed that in fin de siècle Vienna the analytic turn to the inner world of the psyche was a sign of political disillusionment, or that it was counterpolitical. But as these examples from twentieth-century Britain show, the analytic focus on "the war inside" could in fact be profoundly political. See Mariano Plotkin and Joy Damousi, "Introduction," in Damousi and Plotkin, Psychoanalysis and Politics, xi-xvi; and Shapira, The War Inside. 